\title{
Hydro-physical processes and soil properties correlated with origin of soil hydrophobicity
}

\author{
Processos físico-hídricos e propriedades dos solos correlacionadas \\ com a origem de hidrofobicidade nos solos
}

\author{
Eduardo Saldanha Vogelmann ${ }^{\mathrm{I}^{*}}$ José Miguel Reichert $^{\mathrm{I}}$ Juliana Prevedello $^{\mathrm{I}}$ \\ Gabriel Oladele Awe ${ }^{\mathrm{II}}$
}

\section{ABSTRACT}

Hydrophobicity is the phenomenon where the soil has reduced wettability, usually associated with coating of soil particles by hydrophobic organic substances. This study aimed to provide a description of the hydrophobicity occurrence, highlight recent discoveries about the origin of phenomenon and discuss the main hydro-physical properties and chemical processes linked to the development of hydrophobic behavior in soils. Hydrophobicity is associated with other factors such as soil moisture, presence of some fungi species, particle size, soil pH and occurrence of burnings. The causative substances may be provided by local vegetation, through deposition or decomposition. The dependence and combination of different factors that influence hydrophobicity in soils lead to a spatial and temporal variability of the phenomenon, with negative consequences in the processes of infiltration and water percolation, affecting the three-dimensional distribution and dynamics of soil moisture. Thus, the occurrence of a hydrophobic character requires special attention, especially regarding soil use and management.

Key words: hydrophobic, hydrophilic, organic matter, water repellency, soil moisture.

\section{RESUMO}

A hidrofobicidade é o fenômeno em que o solo apresenta dificuldade de se umedecer com a água, normalmente associado ao recobrimento das partículas do solo por substâncias orgânicas hidrofóbicas. Assim, este trabalho tem como objetivo fazer uma descrição da ocorrência da hidrofobicidade, ressaltando as recentes descobertas em relação à origem do fenômeno, enfocando as principais propriedades físico-hídricas e processos físico-químicos ligados ao desenvolvimento do caráter hidrofóbico no solo. As substâncias orgânicas responsáveis pela repelência podem recobrir total ou parcialmente as partículas, agregados e paredes dos poros, transmitindo diferentes graus de hidrofobicidade ao solo. Essas substâncias podem ser oriundas

\begin{abstract}
da vegetação local, via deposição ou decomposição, porém a hidrofobicidade pode estar associada a outros fatores como a umidade do solo, a presença de algumas espécies de fungos, a composição granulométrica, o pH do solo e a ocorrência de queimadas. A dependência e a combinação dos diferentes fatores que influenciam na ocorrência de hidrofobicidade nos solos levam a uma variabilidade espacial e temporal do fenômeno, com consequências negativas nos processos de infiltração e percolação da água, afetando a distribuição tridimensional e dinâmica da umidade do solo. Dessa forma, a ocorrência do caráter hidrofóbico exige uma atenção diferenciada, principalmente em relação ao uso e manejo do solo.
\end{abstract}

Palavras-chave: hidrofóbico, hidrofílico, material orgânico, repelência à água, umidade do solo.

\section{INTRODUCTION}

Hydrophobicity is a phenomenon documented in several countries around the world. The study of JARAMILLO (2004; 2006) showed case studies of hydrophobicity in Latin America and in Europe. Soil hydrophobicity is often regarded as a natural phenomenon generally found on the surface of sandy soils after the occurrence of fires (SAVAGE et al., 1974), or in the subsoil layers resulting from the effect of the growth and development of some fungal species (SAVAGE et al., 1969).

Actually the condition of soil water repellency or hydrophobicity, is usually associated with a coating of soil particles by hydrophobic organic substances. However, JARAMILLO (2006)

\footnotetext{
IDepartamento de Solos, Centro de Ciências Rurais (CCR), Universidade Federal de Santa Maria (UFSM), 97105-900, Santa Maria, RS, Brasil. E-mail: duardovogelmann@hotmail.com. *Autor para correspondência.

IISoil, Crop and Environmental Sciences Department, Ekiti State University (EKSU), Ado Ekiti, Nigeria. Received 05.15.12 Approved 04.12.13 Returned by the author 07.04.13 CR-2012-0246.R1
} 
and VOGELMANN et al. (2010) pointed out that the greatest degree of water repellency may also be present in soils with low organic carbon content, leading to the conclusion that the hydrophobic character is related to the quality and not quantity of these organic compounds. Organic substances responsible for repellency can be of various origins. The local vegetation, depending on their chemical composition, may contribute to hydrophobic organic compounds, by deposition or decomposition (MATAIX-SOLERA et al., 2007). It may also be associated with other factors such as soil moisture conditioned by rain and drought (ROBINSON et al., 2010), the granulometric composition (WOCHE et al., 2005; KAWAMOTO et al., 2007; VOGELMANN et al., 2010), soil pH (BAYER \& SCHAUMANN, 2007) and presence of some species of fungi (SCHAUMANN et al., 2007; WAHL et al., 2008) and burnings (MADSEN et al., 2011, VOGELMANN et al., 2012).

Soil water repellency has become a subject of global concern, with substantial effects on plant production, soil use and management (MÜLLER \& DEURER, 2011). As a primary effect, CERDÀ \& DOERR (2007) cited a reduction in water infiltration and hence the amount of available water will be reduced thereby affecting seed germination, growth and development of vegetation. MOREOVER \& MADSEN et al. (2011) mentioned that, due to reduced infiltration rate, runoff may be increased, especially in hilly areas, accelerating the risk of erosion, especially in places where it is a common occurrence after periods of heavy rains, prolonged drought, or a combination of events that is currently increasing in frequency and intensity due to climate change.

The study of hydrophobicity is still very incipient in Brazil as evidenced by the small number of studies related to the phenomenon. Thus, this study aims to provide a description of the occurrence of hydrophobicity, highlight recent discoveries about the origin of the phenomenon, with a special focus on the main hydro-physical properties and chemical processes linked to the development of hydrophobic character on the soil.

Occurrence and variability of hydrophobicity in the soil Hydrophobicity has been documented in various locations and soil and climatic conditions, found in humid tropical climates (VOGELMANN et al., 2010; CAMBRONERO et al., 2011), in humid and cold climates of northern Europe (DLAPA et al., 2008, WAHL, 2008), or even in regions of warm and dry climate of central Australia (THWAITES et al., 2006) or in Mediterranean climate of southwest Europe
(MATAIX-SOLERA et al., 2007; RODRÍGUEZALLERES et al., 2007; KEIZER et al., 2007). In the literature, there are vast records of this phenomenon in a wide variety of soils, from sandy to clay soils, the highly to low weathered, very acidic to alkaline and fertile to less fertile (MÜLLER \& DEURER, 2011). It can be inferred that hydrophobicity can potentially occur in any soil type (VOGELMANN et al., 2010, 2012).

Another important aspect when studying hydrophobicity is that the phenomenon does not manifest itself permanently, as it appears with maximum intensity in the driest seasons, may decrease or even disappear in the wet season (KEIZER et al., 2007). Prolonged periods of soil drying promote high degree of hydrophobicity and impose a high difficulty in re-wetting, necessitating long periods to wet the soil to restore their wetting properties. This behavior causes changes in the diagnosis of the hydrophobicity degree, generating a temporal variability of the phenomenon in the soil (KEIZER et al., 2007). This submission was confirmed by analyzing the study of RODRIGUEZ-ALLERES et al. (2007), which provides the first systematic analysis of the distribution and persistence of hydrophobicity in wet soils and vegetation in northeastern Spain. The authors found the highest repellency in months with less rainfall and forest vegetation with eucalyptus and pine trees while little or no hydrophobicity was recorded in grassland vegetation and maize crop. Thus, it can be concluded that hydrophobicity varies spatially (RODRIGUEZ-ALLERES et al., 2007) and temporarily (KEIZER et al., 2007).

\section{Concept of hydrophobicity in the soil}

Initially, it was believed that the occurrence of hydrophobicity is associated with burns, in which the heat of the fire vaporizes the hydrophobic compounds of soil organic matter. Since the compounds could move into the atmosphere, they condense on the soil mineral particles and form hydrophobic coatings on such particles (SAVAGE, 1974).

Other theories about the origin of soil hydrophobicity in its manifestation are related to the accumulation of hydrophobic organic compounds, which do not present a very advanced degree of decomposition and do not correspond to humus itself. These compounds are plant root exudates, leaf surface waxes of plant compounds from the metabolism of certain species of fungi and decaying organic matter, usually produced by roots and microorganisms to increase the availability of nutrients or as a defense against drying (HALLET et al., 2003; FEENEY et al., 2006). However, such hydrophobic compounds can 
also be derived from soil contamination with oil or some of its derivatives and due to the occurrence of fires and bush burning (FOX et al., 2007; MATAIXSOLERA et al., 2012).

The concept of hydrophobicity is a relative new one (MATAIX-SOLERA et al., 2012). Hydrophobic soils restrict the entry of water, which 'balls up' or sits on the soil in beads rather than infiltrating the soil (CAMBRONERO et al., 2011). The repellency comes from a mutual attraction between water and solid surfaces (adhesion) or between water molecules (cohesion). When the adhesive forces between water molecules and an object are weaker than the cohesive forces between water molecules, the surface repels water (REZUS \& BAKKER, 2007). The water molecule has one atom of oxygen with a negative charge and two hydrogen atoms with a positive charge, forming a strong bipolar structure where the cations are attracted at the same time to the negatively charged surface and tend to move away from the other end of the positive charge (KLEBER \& JOHNSON, 2010). The attraction of these positive and negative terminals induces water molecules to form as structure maintained by hydrogen bonds, hence the water adhered to other surfaces, for example, the soil particles. However, when the soil is highly humid, the polar ends of the hydrophobic compounds are attracted by the free water and thus the compounds previously adhered to the soil particles are attracted to the solution (KLEBER \& JOHNSON, 2010). Since part of the hydrophobic compounds shows no relationship with water, the hydrophobic compounds tend to cluster together, curled up, reducing the area of direct contact with water, and leaving only the face exposed hydrophilic (DOERR \& THOMAS, 2003).

Hydrophobic molecules do not dissolve in water, but may be immersed or grouped into cells, because water molecules tend to obey the second law of thermodynamics (KLEBER \& JOHNSON, 2010) (Figure 1). The second law of thermodynamics states that an isolated system tends to evolve towards increasing entropy. Thus, all systems must evolve to the maximum entropy. However, near the hydrophilic regions of hydrophobic molecules, water molecules are slow and captured by the other molecules, with reduction in mobility, leading to a decrease in entropy (REZUS \& BAKKER, 2007). Furthermore, the driving force for the aggregation of non-polar molecules through hydrophobic interactions may be related to the tendency of water to reduce the surface area of contact of amphiphilic molecules with liquid, thus reducing the total number of water molecules

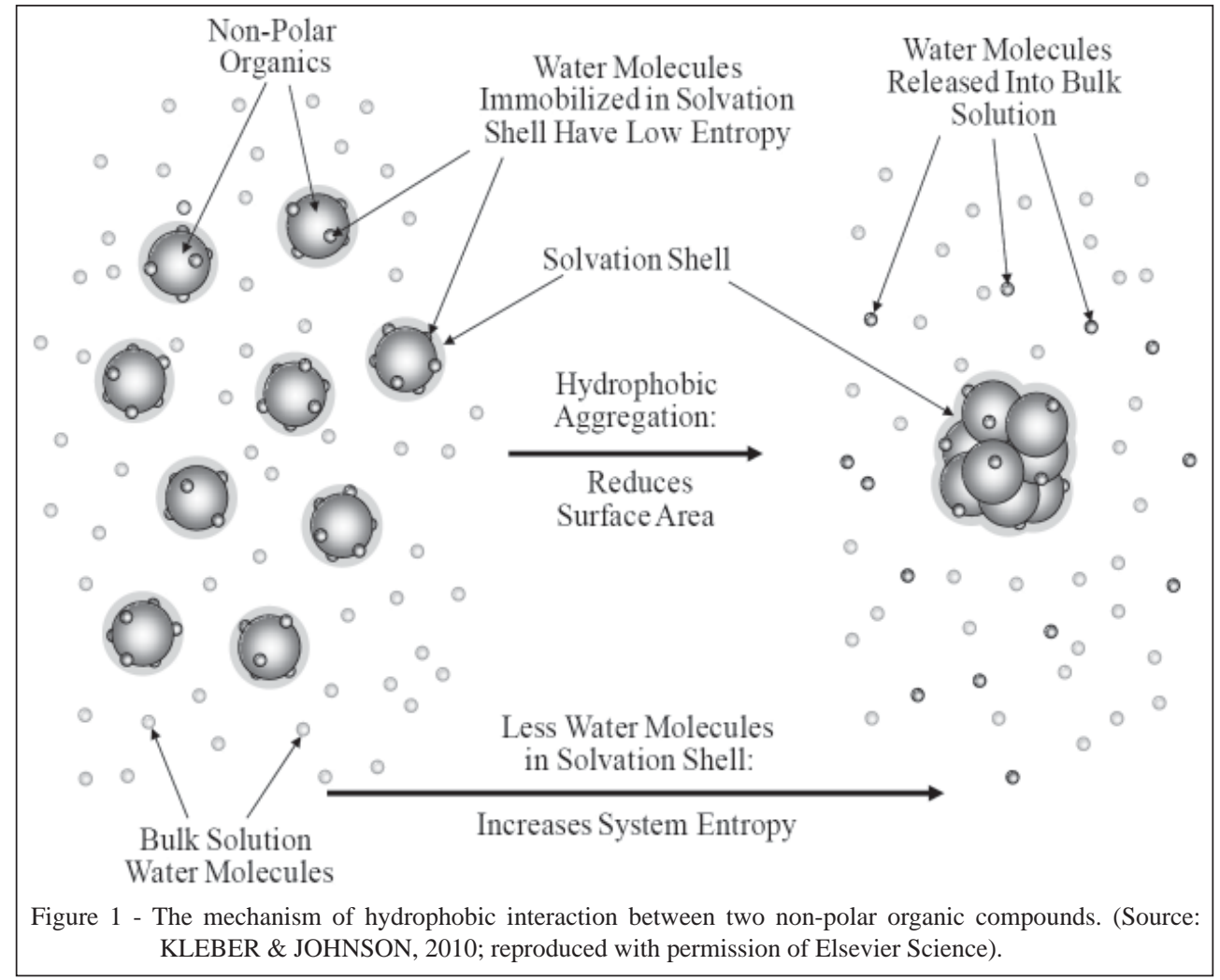

Ciência Rural, v.43, n.9, set, 2013. 
in a "state of low entropy" in the solvation shell of hydrophobic molecules, which are grouped under conditions of high humidity, so the number of water molecules in solution is maximized (REZUS \& BAKKER, 2007). With a reduction in soil moisture, the water films become increasingly smaller and matrix forces larger, with consequent reduction of water activity in the soil (KLEBER \& JOHNSON, 2010). Thus, the hydrophilic groups are oriented toward the water layer, while the hydrophobic chains are oriented toward the air (REZUS \& BAKKER, 2007). When the humidity reaches very low level, the hydrophilic groups (polar) tend to be attracted by the charged particles of the soil, joining its termination to the polar surface of the soil and exposing its nonpolar terminal (hydrophobic side) thereby covering all or part of the particles, aggregates and pore walls (MATAIX-SOLERA et al., 2012).

The main compounds identified with hydrophobic character in the soil can be divided into two groups. The first consists of long chain hydrocarbons and aliphatic structure (CAMBRONERO et al., 2011). These compounds are polar, that is, they have no negative or positive charge at the end of the chain and are almost insoluble in water, showing hydrophobic character (MATAIX-SOLERA et al., 2012). The second group is formed by amphiphilic substances of polar structure, with a hydrocarbon chain (hydrophobic) with terminal functional group of positive or negative charge with hydrophilic character (KLEBER \& JOHNSON, 2010). Organic molecules consisting of long chain fatty acids are the major hydrophobic substances found in soils (CAMBRONERO et al., 2011). However, more research is needed to accurately characterize the chemically compounds that cause water repellency (BAYER \& SCHAUMANN et al., 2007).

Despite the fact that hydrophobic compounds that cause water repellency are organic in nature, some studies showed that there is no relationship between the degree of soil water repellency with organic matter content (JARAMILLO, 2004). However, VOGELMANN et al. (2010) found the existence of this relationship, although with low coefficients of determination and unsatisfactory to make predictions about the eventual manifestation of the phenomenon depending on the particular soil organic matter content. Hence, it can only be viewed as reinforcing the idea that this behavior is not only related to the quantity, but also the composition of organic matter, which will induce the expression of hydrophobicity in the soil (JARAMILLO, 2006; VOGELMANN et al., 2010).
Water content and relationship with hydrophobic soil The hydrophobicity of a soil is not static but varies spatially and temporary, as such, one of the key variables that influences its occurrence is the soil water content (CERDÀ \& DOERR (2007). The relationship between water content and hydrophobicity was the focus of a study by KEIZER et al. (2007), who investigated the variability in space and time in a cultivated soil with potato and maize during a growing season in Portugal. The results confirmed this transient behavior as it changed markedly within three days, depending on the variation of water content in the soil. Hydrophobic organic compounds such as plant root exudates, wax, fungal metabolites, among others, are strongly hydrophilic in a humid environment, but below a critical threshold of moisture (ROBINSON et al., 2010). The surfaces are strongly hydrophilic, grouping itself with one another, partially or completely surrounding the soil particles and aggregates, and leaving an exposed hydrophobic surface (DE GREYZE et al., 2006). These findings were also reported by Robinson et al. (2010), who concluded that a soil is likely to show hydrophobicity when it is below a critical level of humidity. Moreover, its behavior can change abruptly, from wettable to non-wettable, as a result of reduction in water content (KEIZER et al., 2007; THWAITES et al., 2006). On the opposite side of the scale, a prolonged wetness can reverse this behavior and such soil can become hydrophilic and therefore recover its wettability (MATAIX-SOLERA \& DOERR, 2004).

In hydrophilic soils with low water content, it is generally expected that the initial wetting process will be faster due to the high forces of attraction that exist between soil solids and water (VOGELMANN, 2011). However, this process can be extremely slow, even in the dry soils, thereby exhibiting hydrophobicity as verified by MADSEN et al. (2011). These authors reported that there is a transition zone or zone of critical soil moisture defined by two moisture contents. First, the lower limit which determines the minimum amount of water below which the soil is water repellent, and the other, which determines the water content above which the soil is wettable (KEIZER et al., 2007, VOGELMANN, 2011). However, some soils, although having repellence tendency, retained significant water content, due to their size fractions and organic matter content. For instance, DOERR \& THOMAS (2003) found values of soil moisture from 0.14 to $0.22 \mathrm{~g} \mathrm{~g}^{-1}$ for the lower and upper parts of a repellent soil respectively. TÄUMER et al. (2005) measured soil water contents in this transition zone 
and found the values ranging from 0.03 to $0.18 \mathrm{~g} \mathrm{~g}^{-1}$. Thus, the authors affirmed that samples with high water content did not show high hydrophobicity, in contrast to samples with lower water content which recorded higher water repellence.

The rate of water intake in a non-repellent dry soil is high initially and decreases experimentally after a certain time. In contrast, in a water repellent soil, the infiltration rate at the beginning of the wetting process is very slow or may be zero (VOGELMANN, 2011). According to DOERR et al. (2006), the flow of water between the aggregates can be enhanced due to hydrophobicity, which may result in an irregular wetting front. Another feature observed by DOERR \& THOMAS (2003) is that the water repellency reaches zero when soil moisture is near field capacity and increases between dry soil and permanent wilting point, the maximum being near the lower repellence humidity.

Relationship between hydrophobicity and soil granulometric composition

In addition to organic matter content, soil particle size also has an intrinsic relationship with hydrophobicity (DOERR et al., 2006). The first studies that sought to relate the occurrence of hydrophobicity with the granulometric composition reported that the phenomenon were mainly present in sandy soils (MEEUWIG, 1971). Recent studies too indicated that extreme cases of water repellency were found in sandy soils (DOERR et al., 2006; WAHL, 2008). These authors explained that the high hydrophobicity in sandy soils is related to the ease of coating of coarse particles by hydrophobic substances, due to smaller specific surface area. WOCHE et al. (2005) found high degree of repellency in soil samples with clay content ranging from 25 to $40 \%$ and reported that the water repellency decreases with decreasing particle size and also with increasing soil depth, the reduction being more pronounced in clay soils than in sandy soils. This is closely related to the distribution of organic matter on soil surface, as described by JARAMILLO, 2006 and De GRYZE et al. (2006), who found in smaller fractions of the soil the highest degree of hydrophobicity, given the highest organic material content associated with these fractions. However, despite the susceptibility of soils with sandy texture to water repellency, there are several records of hydrophobicity in clay or fine texture-soils (TÄUMER et al., 2005; KAWAMOTO et al., 2007). The high repellency in clay soils occurs because clay particles form aggregates, reducing the surface area which might be covered with a thin layer of hydrophobic substances (KAWAMOTO et al., 2007; VOGELMANN et al., 2010). Other studies showed that in certain environments, the contribution of hydrophobic material can be so high in addition to coating coarser particles, also coating by organic material part of the fine particles (WOCHE et al., 2005; KAWAMOTO et al., 2007; FOX et al., 2007).

The degree of hydrophobicity depends on the proportion of soil particles with a hydrophobic surface layer, which is influenced by the specific surface area and varies considerably with soil texture (WAHL, 2008). Sandy soils have a lower specific surface area, so a hydrophobic surface will push a greater proportion of particles than in the case of a silt clay soil or where the specific surface area is larger (TÄUMER et al., 2005; WOCHE et al., 2005). In addition, sandy soils also provide a better habitat for fungi than bacteria, due to the low particle surface area and pore size distribution, which is a poor habitat for bacteria (HALLET et al., 2003; BAYER \& SCHAUMANN et al., 2007).

Other factors related to hydrophobicity

In addition to moisture, particle size and soil organic matter, compounds also related to hydrophobicity are substances such as extracellular polymers produced by bacteria or fungi (MATAIXSOLERA et al., 2007; RODRIGUEZ-ALLERES et al., 2007; WAHL, 2008). Biofilms exudates can induce or remove the repellency soil materials depending on the strain bacteria (SCHAUMANN et al., 2007). Although it is difficult to study the factors separately, besides bacteria, fungal biomass is also cited as causing soil hydrophobicity (FEENEY et al., 2006). Microbial activities, which result in addition of nutrients through the decomposition of plants, affect soil physical processes such as water movement and retention and aggregate stability (MATAIX-SOLERA et al., 2007; WAHL, 2008). But probably the major influence on water repellency is linked to the production of microbial biomass (hyphae) and exudates that change the characteristics of the hydraulic connection between soil and particles (SCHAUMANN et al., 2007). This reduction in damping caused by increased hydrophobicity has serious implications for soil management, affecting growing conditions and enhancing the flow of water between aggregates (KAWAMOTO et al., 2007). The soil around plant roots, called the rhizosphere, may also have a higher rate of soil hydrophobicity alone (HALLET et al., 2003). Specific combinations produced by plant roots can induce hydrophobicity, especially when associated with the effects of secondary metabolites from microbial decomposition 
of these roots (MATAIX-SOLERA et al., 2007; RODRIGUEZ-ALLERES et al., 2007).

A recent study by Bayer \& SCHAUMANN (2007) shifted the focus to other factors affecting water repellency towards the influence of drying conditions and soil $\mathrm{pH}$. Both are frequently mentioned as potential drivers of hydrophobicity in the soil, but little data exists. In the study, the authors found a positive correlation between changes in $\mathrm{pH}$ and the index of hydrophobicity. MATAIX-SOLERA \& DOERR (2004) investigated the occurrence of hydrophobicity in calcareous soils under four tree species in semi-arid region of eastern Spain and found that the levels of water repellency was relatively low, and the $\mathrm{pH}$ showed the highest (negative) compared with the persistence of water repellency. BAYER \& SCHAUMANN (2007) and MATAIX-SOLERA et al. (2007) found that $\mathrm{pH}$ above 6.5 reduces the water repellency of some soils.

Fires and bush burning are also cited as probable causes of hydrophobicity in soils (MATAIXSOLERA et al., 2012). During burning, hydrophobic substances are formed that become strongly cemented in the top layer of soil and may result in the formation of water repellent layers and increased potential for erosion losses (FOX et al., 2007, MADSEN et al., 2011). DLAPA et al. (2008) and VOGELMANN et al. (2012) added that bush burning causes heating of the soil, thus creating a water repellent surface layer due to changes in the conformation of organic compounds existing mainly by condensation of hydrophobic organic chemicals on the soil surface which are associated with drying.

\section{CONCLUSION}

Dependence and/or the combination of different factors that influence the occurrence of hydrophobicity in soils lead to a spatial and temporal variability of the phenomenon, with negative consequences in the processes of infiltration and percolation of water, resulting in the development of uneven subsurface flows, affecting the threedimensional distribution and dynamics of soil moisture.

The occurrence of a hydrophobic character requires special attention, especially regarding the soil use and management. As a primary effect, it reduces the rate of water infiltration into the soil and hence the amount of available water is diminished and may indirectly affect plant emergence and cause downtime of fertilizers and pesticides that need to be solubilized to act properly. In addition, due to reduced infiltration rate, there may be increased runoff, especially in hilly areas, accelerating erosion risks. Thus, research is needed in order to advance specific knowledge of the processes involved in hydrophobicity, the effects and behavior over time, with a view to predicting the occurrence of problem soils and advance techniques and alternatives that will minimize negative effects on crops of interest. Research is also needed to relate the occurrences of soil hydrophobicity on the type of hydrophobic substances with a view to elucidating the interactions between vegetation, organisms, and physical and chemical properties and the main factors that are linked to the occurrence of this phenomenon in the soil. Moreover, it is important to investigate the effects of hydrophobicity on natural environments to understand their role and importance in natural ecosystems as a mechanism for protecting plants and not only harmful effects.

Studies are needed to focus on the determination of plant species and environmental characteristics that may be correlated with the presence of hydrophobic compounds. In addition to studies directed at understanding the dynamics of these compounds, their release until total decomposition should be monitored in order to understand the interactions and relationships with soil organic matter, plants and other organisms in space and time. Based on this, attempts can be made in relation to mitigating the effects and the development of strategies for prevention or management of soil hydrophobicity.

It should be emphasized that the problems of water availability, which already plagued many countries, are expected to increase significantly in the coming years, mainly due to global climate change, which has resulted into the significant changes in precipitation in various locations. As a result, the impacts of hydrophobicity on agricultural production will become increasingly evident in many countries. Thus, studies related to mitigation of hydrophobicity are essential with a view to maximizing the use and benefits of water resources that are becoming scarce.

Finally, it is necessary to break some paradigms, especially those related to the negative views of the occurrence of soil hydrophobicity as reported in somestudies. Contrary to this, recent studies have shown positive aspects of soil hydrophobicity, such as, enhancement of soil aggregate stability and reduction in evaporation especially in situations of stress or low rainfall. Therefore, it is still necessary to explore and investigate the ecological importance of soil water repellency, which may be a useful tool in stimulating and increasing the productivity of agricultural systems. 


\section{REFERENCES}

BAYER, J.V.; SCHAUMANN, G.E. Development of soil water repellency in the course of isothermal drying and upon $\mathrm{pH}$ changes in two urban soils. Hydrological Processes, v.21, p.2266-2275, 2007. Available from: <http://onlinelibrary.wiley. com/doi/10.1002/hyp.6759/pdf $>$. Accessed: Abr. 19, 2012. doi: 10.1002/hyp.6759.

CAMBRONERO, Y.C. et al. Influência da concentração de extratos hidrofóbicos na repelência à água em solos arenosos. Pesquisa Florestal Brasileira, v.31, p.01-08, 2011. Available from: <http://www.cnpf.embrapa.br/pfb/index.php/pfb/article/view/79>. Accessed: Abr. 19, 2012. doi: 10.4336/2011.pfb.31.65.01.

CERDÀ, A.; DOERR, S.H. Soil wettability, runoff and erodibility of major dry-Mediterranean land use types on calcareous soils. Hydrological Processes, v.21, p.2325-2336, 2007. Available from: <http://onlinelibrary.wiley.com/doi/10.1002/hyp.6755/pdf>. Accessed: Abr. 19, 2012. doi: 10.1002/hyp.6755.

DE GRYZE, S. et al. Water repellence and soil aggregate dynamics in a loamy grassland soil as affected by texture. European Journal of Soil Science, v.57, p.235-246, 2006. Available from: <http://onlinelibrary.wiley.com/doi/10.1111/ j.1365-2389.2005.00733.x/pdf>. Accessed: Abr. 19, 2012. doi: 10.1111/j.1365-2389.2005.00733.x.

DLAPA, P. et al. Application of thermal analyses to elucidate water repellency changes in heated soils. Soil Science Society of America Journal, v.72, p.1-10, 2008. Available from: <https:// www.soils.org/publications/sssaj/pdfs/72/1/1>. Accessed: Abr. 19, 2012. doi: $10.2136 /$ sssaj2006.0280.

DOERR, S.H. et al. Extraction of compounds associates with water repellency in sandy soils of different origin. Australian Journal of Soil Research, v.43, p.225-237, 2005. Available from: $<$ http://www.publish.csiro.au/?act=view file\&file id=SR04091. pdf>. Accessed: Abr. 19, 2012. doi: 10.1071/SR04091.

DOERR, S.H. et al. Occurrence, prediction and hydrological effects of water repellency amongst major soil and land use types in a humid temperate climate. European Journal of Soil Science, v.57, p.741-754, 2006. Available from: <http://onlinelibrary.wiley. com/doi/10.1111/j.1365-2389.2006.00818.x/pdf >. Accessed: Abr. 19, 2012. doi: 10.1111/j.1365-2389.2006.00818.x.

DOERR, S.H.; THOMAS, A.D. Soil moisture: a controlling factor in water repellency? In: RITSEMA, C.J.; DEKKER, L.W. Soil water repellency: occurrence, consequences and amelioration. Amsterdam: Elsevier Science, 2003. Cap.14, p.137-149.

FEENEY, D.S. et al. Impact of fungal and bacterial biocides on microbial induced water repellence in arable soil. Geoderma, v.135, p.72-80, 2006. Available from: <http://www.sciencedirect. com/science/article/pii/S0016706105003022>. Accessed: Abr. 19, 2012. doi: 10.1016/j.geoderma.2005.11.007.

FOX, D.M. et al. Effects of fire-induced water repellency on soil aggregate stability, splash erosion, and saturated hydraulic conductivity for different size fractions. Hydrological Processes, v.21, p.2377-2384, 2007. Available from: <http://onlinelibrary. wiley.com/doi/10.1002/hyp.6758/pdf>. Accessed: Abr. 19, 2012. doi: 10.1002/hyp.6758.

HALLETT, P.D. et al. Plant influence on rhizosphere hydraulic properties: direct measurements using a miniaturized infiltrometer.
New Phytologist, v.157, p.597-603, 2003. Available from: <http:// onlinelibrary.wiley.com/doi/10.1046/j.1469-8137.2003.00690.x/ pdf>. Accessed: Abr. 19, 2012. doi: 10.1046/j.14698137.2003.00690.x.

JARAMILLO, J.D.F. Repelencia al agua en suelos: con énfasis en Andisoles de Antioquia. Medellin: Universidad Nacional de Colombia, 2004. 197p.

JARAMILLO, J.D.F. Repelencia al agua en suelos: Una síntesis. Revista de la Académica Colombiana de Ciencia, v.30, p.215232, 2006. Available from: <http://www.accefyn.org.co/revista/ Vol_30/115/115_215_232.pdf>. Accessed: Abr. 19, 2012.

JOHNSON, M.S. et al. Spatial and temporal variability of soil water repellency of Amazonian pastures. Australian Journal of Soil Research, v.43, p.319-326, 2005. Available from: <http:// www.publish.csiro.au/?act=view_file\&file_id=SR04097.pdf $>$. Accessed: Abr. 19, 2012. doi: 10.1071/SR04097.

KAWAMOTO, K. et al. Water repellency of aggregate size fractions of a volcanic ash soil. Soil Science Society of America Journal, v.71, p.1658-1666, 2007. Available from: <https://www. soils.org/publications/sssaj/pdfs/71/6/1658>. Accessed: Abr. 19, 2012. doi: 10.2136/sssaj2006.0284.

KEIZER, J.J. et al. Temporal and spatial variations in topsoil water repellency throughout a crop-rotation cycle on sandy soil in north-central Portugal. Hydrological Processes, v.21, p.2317-2324, 2007. Available from: <http://onlinelibrary.wiley. com/doi/10.1002/hyp.6756/pdf>. Accessed: Abr. 19, 2012. doi: 10.1002/hyp.6756

KLEBER, M.; JOHNSON, M.G. Advances in understanding the molecular structure of soil organic matter: implications for interactions in the environment. In: SPARKS, D.L. Advances in Agronomy. Amsterdam: Elsevier Science, 2010. Cap.3, p.77-142.

MADSEN, M.D. et al. Soil water repellency within a burned pinon-juniper woodland: spatial distribution, severity, and ecohydrologic implications. Soil Science Society of America Journal, v.75, p.1543-1553, 2011. Available from: <https://www. soils.org/publications/sssaj/pdfs/75/4/1543>. Accessed: Abr. 19, 2012. doi:10.2136/sssaj2010.0320.

MATAIX-SOLERA, J. et al. Soil properties as key factors controlling water repellency in fire-affected areas: evidences from burned sites in Spain and Israel. Catena, 2012. Available from: <http:// www.sciencedirect.com/science/article/pii/S0341816211002414>. Accessed: Abr. 19, 2012. doi:10.1016/j.catena 2011.12.006.

MATAIX-SOLERA, J. et al. Water repellency under different plant species in a calcareous forest soil in a semiarid Mediterranean environment. Hydrological Processes, v.21, p.2300-2309, 2007. Available from: <http://onlinelibrary.wiley.com/doi/10.1002/hyp.6750/ pdf>. Accessed: Abr. 19, 2012. doi: 10.1002/hyp.6750.

MATAIX-SOLERA, J.; DOERR, S.H. Hydrophobicity and aggregate stability in calcareous topsoils from fire-affected pine forest in southeastern Spain. Geoderma, v.118, p.77-88, 2004. Available from: <http:/www.sciencedirect.com/science/article/pii/ S001670610300185X>. Accessed: Abr. 19, 2012. doi: 10.1016/ S0016-7061(03)00185-X. 
MEEUWIG, R.O. Infiltration and water repellency in granitic soils. Ogden: Intermountain Forest and Range Experiment Station, 1971. 20p.

MÜLLER, K.; DEURER, M. Review of the remediation strategies for soil water repellency. Agriculture, Ecosystems \& Environment, v.144, p.208-221, 2011. Available from: <http:// www.sciencedirect.com/science/article/pii/S0167880911002878>. Accessed: Abr. 19, 2012. doi: 10.1016/j.agee.2011.08.008.

REZUS, Y.L.A.; BAKKER, H.J. Observation of immobilized water molecules around hydrophobic groups. Physical Review Letters, v.99, p.10728-10731, 2007. Available from: <http://prl. aps.org/pdf/PRL/v99/i14/e14830>. Accessed: Abr. 19, 2012. doi: 10.1103/PhysRevLett.99.148301.

ROBINSON, D.A. et al. Soil water repellency: A method of soil moisture sequestration in pinyon-juniper woodland. Soil Science Society of America Journal, v.74, p.624-634, 2010. Available from: <https://www.soils.org/publications/sssaj/pdfs/74/2/624>. Accessed: Abr. 19, 2012. doi: 10.2136/sssaj2009.0208.

RODRÍGUEZ-ALLERES, M. et al. Extent and persistence of water repellency in north-western Spanish soils. Hydrological Processes, v.21, p.2291-2299, 2007. Available from: <http:// onlinelibrary.wiley.com/doi/10.1002/hyp.6761/pdf>. Accessed: Abr. 19, 2012. doi: 10.1002/hyp.6761.

SAVAGE, S.M. Mechanism of fire-induced water repellency in soil. Soil Science Society of America Proceedings, v.38, p.652657, 1974

SAVAGE, S.M. et al. Contribution of some soil fungi to natura and heat-induced water repellency in sand. Soil Science Society of America Proceedings, v.33, p.405-409, 1969.

SCHAUMANN, G.E. et al. Influence of biofilms on the wate repellency of urban soil samples. Hydrological Processes, v.21, p.2276-2284, 2007. Available from: <http://onlinelibrary.wiley. com/doi/10.1002/hyp.6746/pdf>. Accessed: Abr. 19, 2012. doi: 10.1002/hyp
TÄUMER, K. et al. Determination of repellency distribution using soil organic matter and water content. Geoderma, v.125, p.107-115, 2005. Available from: <http://www.sciencedirect.com/ science/article/pii/S0016706104001880>. Accessed: Abr. 19, 2012. doi: 10.1016/j.geoderma.2004.07.004

THWAITES, L.A. et al. Near-surface distributions of soil water and water repellency under three effluent irrigation schemes in a blue gum (Eucalyptus globulus) plantation. Agricultural Water Management, v.86, p.212-219, 2006. Available from: <http://www. sciencedirect.com/science/article/pii/S037837740600196X>. Accessed: Abr. 19, 2012.

VOGELMANN, E.S. et al. Soil hydro-physical changes in natural grassland of southern Brazil subjected to burning management. Soil Research, v.50, p.465-472, 2012. Disponível em: <http:// www.publish.csiro.au/paper/SR12106.htm>. Accessed: Abr. 09, 2013. doi:10.1071/SR12106.

VOGELMANN, E.S. et al. Water repellency in soils of humid subtropical climate of Rio Grande do Sul, Brazil. Soil \& Tillage Research, v.110, p.126-133, 2010. Available from: <http:// www.sciencedirect.com/science/article/pii/S016719871000120>. Accessed: Abr. 19, 2012. doi:10.1016/j.still.2010.07.006.

VOGELMANN, E.S. Ocorrência de hidrofobicidade em solos do Rio Grande do Sul. 2011. 124f. Dissertação (Mestrado em Ciência do Solo) - Curso de Pós-graduação em Ciência do Solo, Universidade Federal de Santa Maria, RS.

WAHL, N.A. Variability of water repellency in sandy forest soils under broadleaves and conifers in north-western Jutland/Denmark. Soil and Water Research, v.3, p.155-164, 2008. Available from: <http://www.agriculturejournals.cz/publicFiles/01673.pdf>. Accessed: Abr. 19, 2012.

WOCHE, S.K. et al. Contact angle of soils as affected by depth, texture and land management. European Journal of Soil Science, v.56, p.239-251, 2005. Available from: <http://onlinelibrary.wiley. com/doi/10.1111/j.1365-2389.2004.00664.x/pdf>. Accessed: Abr. 19, 2012. doi: 10.1111/j.1365-2389.2004.00664.X. 